\title{
Start up India: Challenges \& Opportunities
}

\author{
Kamaldeep Kaur,AP \\ Department of Management \\ Gulzar Group of Institutes \\ Ludhiana,, India \\ Kamaldeep.kaur@ggi.ac.in
}

\begin{abstract}
Due to globalization and advancement in technology competition is increasing day by day that's why self- employment consciousness among college students is increasing at fast pace. Furthermore India is second most populous country and due to large population pressure it is need of hour to develop entrepreneurial skill among people in India so government launch startup India Plan to support young inspiring entrepreneur. This Paper aims to investigate the challenges and Opportunities in the way of startups in India. This paper is intent to explore the major difficulties faced by startups in India, and discuss the various opportunities of startups in India by using a literature-based analysis.
\end{abstract}

\section{Keywords}

Startups, Entrepreneurship, regulatory clearances, culture.

\section{Academic Discipline And Sub-Disciplines}

Academic displine is Management and Sub displine is Human Resource Management

\section{SUBJECT CLASSIFICATION}

Entrepreneurship

\section{TYPE (METHOD/APPROACH)}

Paper is based on literature based analysis.

\section{INTRODUCTION}

Because of globalization and headway in innovation rivalry is expanding step by step that is the reason as of late the independent work cognizance among undergrads are expanding and the understudies are more averse to depend on guardians or schools or sit tight for circumstances. Rather, they tend to step up with regards to search for new possibilities for themselves. Nation like India which is seventh-greatest nation by territory and the second-most crowded nation with more than 1.2 billion individuals and it is notable that expansive populace prompts to substantial work weight in Indian culture so it is need of our hour to create entrepreneurial aptitude among individuals so they can't exclusively depend on employment and they can begin their own business and Indian government has dispatch Startup India to bolster moving business visionaries [1]. A considerable measure of elements, including the globalization and ascent of IT industry in the 90s was significantly in charge of the ascent of business enterprise in India. Today, Indian Economy is experiencing an inestimable remodel with new procedures moving into the market underlining and improving the part and commitment of new businesses [2]. To make responsiveness and organizing an entrepreneurial situation, a great deal of accentuation ought to now be given to making foundation for coaching new companies. Different partners, for example, the administration, organizations, instructive establishments and others are and ought to hold hands to construct a superior ecosystem for youngsters.

A new business or startup or start-up is a youthful organization that is recently starting to create. New companies are generally little and initially financed and worked by a modest bunch of authors or one person. These organizations offer an item or administration that is not at present being offered somewhere else in the market, or that the originators accept is being offered in a mediocre way [1]. As indicated by the Indian government notice, a substance will be recognized as a startup a) Till up to five years from the date of joining. b) If its turnover does not surpass 25 crores in the last five money related years. c) It is working towards modernization, advancement, sending, and commercialization of new items, procedures, or administrations driven by innovation or protected innovation [2]. In the early stages, new businesses' regular consumption have a tendency to surpass their incomes as they work on creating, testing and showcasing their thought. In that capacity, they regularly require financing. New companies might be supported by regular independent venture advances from banks or credit unions, by state-supported. Private venture Administration advances from nearby banks, or by awards from not-for-profit associations and state governments [1]. New companies typically have been neighborhood endeavors keep running by private venture business people. Today, with Internet's worldwide achieve, business people can tap organizes and build up Start-ups work the whole way across the world. Worldwide IT advancement groups and different sorts of human capital, Start-Ups are rising in zones past the run of the mill US rearing grounds of Silicon Valley, Boston, New York, Washington D.C. what's more, Dallas. An expansion in specialized development and start-up action is presently additionally being found in urban communities, for example, Bangalore, Helsinki, London, Shanghai, Singapore, Sydney, Tel Aviv, Toronto and Zurich India has the fourth biggest biological system on the planet for Start-ups, after the US, the UK and Israel, with a quickly advancing environment, driven by a to a great degree youthful, differing and comprehensive entrepreneurial scene. India is among the main five nations on the planet regarding new companies. US positions number one on the rundown with $83,000+$ new businesses. It is normal 
that if the present pattern proceeds, inside 1-2 years India will achieve the second spot after the US and will be among the top Asian start-up biological systems, alongside China and South-east nations. As indicated by the NASSCOM India Startup Story 2014, around 11,500 Start-ups will come up in the nation by 2020, making more than 2.5 lakh occupations, contrasted with the current 75,000 employments. As per a report by I Spirit, the Top 30 programming item Start-ups in India are presently esteemed at USD 10.25 billion, a 20\% expansion from October 2014 - these Start-ups make utilization of 21,200 individuals and has $80 \%$ of their client base abroad. As indicated by ASSOCHAM, India's Start-ups are relied upon to deliver no less than a score of very rich people and numerous more tycoons in the coming five years, with web based business, money related administrations and innovation driven fields producing most extreme premium [3].

\section{A Start ecosystem}

A Start ecosystem is shaped by individuals, new businesses in their different stages and different sorts of associations in an area (physical as well as virtual), collaborating as a framework to make new businesses. As startup system are by and large characterized by the system of communications among individuals, associations and their condition, they can come in many sorts however are generally also called startup environments of particular urban communities or online groups. Start-up environments are controlled by both outer and interior elements. Outer elements as monetary atmosphere, enormous market interruptions and huge organizations moves, control the general structure of a biological community and the way things work inside it. Start-up biological systems being alert elements-constantly, they are at first in arrangement stages and once settled are liable to intermittent aggravations (like the monetary air pockets) passing thereafter to the recuperating procedure from some of those past unsettling influences. Start-up ecosystems in similar environments but located in different parts of the world can end up doing things differently simply because they have a different entrepreneurial culture and resources pool. The introduction of non-native people knowledge and skills can also .Inward components control ecosystem as well as controlled by them and are frequently subject to input circles. While a portion of the asset sources of info are by and large controlled by outside procedures like money related atmosphere and market interruptions, the accessibility assets inside the biological system is controlled by interior variables like individuals and associations capacity to contribute towards the environment. Other inner components incorporate new companies achievement and disappointments progression along sorts of individuals and accessible abilities. Despite the fact that individuals exist and work inside biological systems, their total impacts are sufficiently huge to impact outer components like money related atmosphere [4].With over $\$ 5$ billion worth interest in 2015 and three to four new businesses developing each day, India has cleared its approach to secure the third position on the planet as far as the quantity of new companies, 4200 and numbering, a development of $40 \%$, before the finish of 2015 . The most recent report by industry body NASSCOM and Zinnov, breaks down the present situation and developing patterns over the different measurements that characterize the Indian startup ecosystem, and gage India's position as a worldwide startup center that is getting to be distinctly alluring for financial specialists, new businesses, and corporate. According to the measurements given in the report, the quantity of dynamic financial specialists in the environment has developed from 220 in 2014 to 490 in 2015 , portraying a 2.3X development. Assist, 8 out of each 10 beat VC/PE Firms in India are remote, and worldwide interest in the Indian startup is prompting to an expanded FDI.

India fills in as the quickest developing startup-base worldwide and stands third in innovation driven item new businesses soon after US and UK separately. The report uncovers that the blast in the startup biological community has created work for around 80,000 to 85,000 individual's altogether. Over $65 \%$ of the new businesses are situated in NCR, Mumbai and Bangalore. The details on the demography of the ecosystem says that $72 \%$ of the organizers are under 35 years of age making India home to the most youthful business people on the planet, with sexual orientation separation of $91 \%$ male and $9 \%$ female. Larger part of the 1200 new businesses are B2C, principally introduce in 3 sections specifically ecommerce, purchaser administrations and aggregators took after by hyperlocal, wellbeing tech, edu-tech and investigation [5].

\section{Startup business challenges}

In current years, the Indian startup organize has truly taken off and made its mark-driven by elements, for example, enormous subsidizing, combination exercises, advancing innovation and an expanding local market however it has long approach there are different obstacle come in method for Startup on the grounds that many controlling powers introduce in condition will ruin entire amusement. Development of business is to a great extent rely on upon government direction since government assume real part in building business person in the nation however youthful moving business person surmise that due protracted methodology and customs it is extremely hard to work together in India and world bank report totally bolster their feeling in light of the fact that as indicated by this report India is positioned 130th out of 189 economies on the effortlessness of working together, 133rd on the simplicity of exchanging crosswise over fringes and 157th on the simplicity of paying charges besides India is positioned 155th if there should arise an occurrence of beginning a business. Growing business visionaries need to make various excursions to government workplaces to enlist and look for clearances. Critical need to scrap various administrative clearances so first significant test is bring monetary and money related change so it get to be distinctly less demanding for working together and youthful moving business visionary to seek after their fantasy of getting to be distinctly fruitful businesspeople. Second greatest test confronted by Indian business visionary is that on a normal, Indian organizations need to make 33 assess installments every year with around 243 hours spent to get ready and pay charges in a year and conversely, China requires only nine expense installments every year, while the US doesn't inconvenience its citizens more than 11 times every year for duty installments. Charges like octroi, VAT, extract makes issues for business people while beginning up a business. NASSCOM has batted for the exception of both immediate and roundabout assessments for all new businesses in India. Tax assessment is a boundary for innovation appropriation and turns out to be a tremendous obstacle for potential business people. With tax collection off the beaten path, new businesses will have the capacity to stem the money outpouring so government needs to start some 
critical change in nations impose structure so individuals don't feel taxation rate. Thirdly most authors of fizzled new businesses feel that the absence of legitimate direction and mentorship is a noteworthy purpose for their disappointment. Individuals everywhere are ignorant about how they can add to monetary development, produce work, and add to social improvement so they require appropriate direction which will help them to answer most normal inquiries for anybody to end up distinctly a business visionary like a)What to do that is issue identified with making a business thought, discovering business opportunity or having a dream $b$ ) Why to do manage issues identified with reward/motivating force examination, hazard assessment or whatever other advantages $\mathrm{c}$ ) How to do: issues identified with legalities and necessities, for example, clearances, licenses, endorsements required. Issues identified with asset accessibility including funds, innovation and labor supply. Additionally Indian individuals are cognizant about hazard and reward that is the reason they give more noteworthy significance to government employments since they give employer stability. Afterward, higher pay scales and great advantages offered by a few private areas or multinational organizations give development openings so it greatest test to change state of mind of individuals and urge them to wind up business person where individuals need to begin from starting and orchestrate assets by their own. Shot of disappointment is progressively when individuals begin their own particular business and Indian culture has adapted individuals to look downward on disappointment. For disappointments, feelings do stop by yet consolation once in a while so. Enterprise is frequently about coming up short and pick up involvement from those disappointments and starting from the very beginning once more. Individuals need to begin tolerating disappointments and permit fresh opportunities. The following trial of startup is to manage to a great extent disorderly and divided Indian markets that make a detour for a startup to succeed. The most complex variable is conduct of Indian customer changes in each $30-50 \mathrm{~km}$ that makes it truly troublesome for a startup to make business or market procedure for their items or administrations. Most new companies by and large stall out in dormancy and step by step close down. An imperative issue confronted by new companies is identified with area of their business. India is a nation of assorted culture and flavor and along with these lines, each item won't not be invited similarly in each district. Proper IT-framework has turned into a requirement for Indian organizations given the developing number of shoppers online - It is absolutely basic for new organizations to set up their laborers for dealing with basic customer information, for instance, that of Master card numbers and related data. Most new organizations have a B2B plan of activity. This is the place digital danger may ascend as they don't know about conceivable dangers that may exist for their new company - No move down arrangement to stay with the startup running when a mischance decimates some key gear in their server farm. Most new companies are self/family subsidized with constrained workforce who makes it hard to keep up records both money related and operational. Capital and access to capital has been an unending issue for new organizations Government and private division budgetary masters have set aside funds through hypothesis channels yet they are not open for a wide range of business. The greatest emergency for such associations has been to pull in financial specialists and pick up their trust with respect to their method of operations - In the underlying period of operations, new businesses don't get subsidizing from banks given no record as a consumer of the firm. Also, there is set number of FICO score firms for little and medium estimated undertaking. In spite of having raised great speculations, new businesses battle to survive the opposition. For a startup, it is especially hard to pull in and procure ability and gifted laborers. A startup frequently can't coordinate the pay rates drawn everywhere scale organizations nor is a vocation at a startup seen as a safe one. This implies new companies confront extreme procuring challenges and now and again need to settle for the following best alternative [6].

\section{OPPORTUNITIES FOR STARTUPS}

There is renowned saying that "each coin has two sides" so start up has made abundant open doors for youthful Indian populace. As indicated by the most recent UN articulation India with 356 million 10-24 year-olds have the real centralization of youth populace regardless of having a littler populace than China. Youth is the main thrust behind advancement, creation, and the future pioneers of a nation besides Youth likewise drives request and utilization design in a nation. For new companies youth make up the workforce that it so urgently needs and going ahead youth can be a gigantic ability base for new businesses and most appropriate to address rising nations' difficulties since India has an interesting arrangement of issues that need advancements to start out of the nation issues around its wellbeing, instruction, foundation, sanitation are one of a kind to the nation and arrangements from western world can't settle it. Every issue gives an interesting chance to new companies to fathom some basic issue and in the meantime create a business around it. What aides are that most issues around rising economies are connected in nature and arrangements appropriate here can likewise work in different nations of Africa and somewhere else. This empowers Indian new companies to procure a significantly greater scale and in the meantime have an important effect far and wide. The number of inhabitants in India is a gigantic resource for the nation in the following couple of years. By 2020, it is assumed that the country will encounter a "statistic reward" period where the working age populace would surpass the non-working populace. This unmistakable statistic preferred standpoint will offer an extraordinary chance to any firm or association attempting to wind up distinctly effective and make a predominant position in the Indian market. India is good to go to split away the customary profession ways as a considerable measure of ability is tending towards working with the Indian startup space [7]. Testing assignments, tremendous subsidizing that brings huge remuneration bundles and a related cool remainder are making new businesses an exceptionally lucrative place and engaging vital offer. Progressively, a pattern is being seen where a few mid-level authorities are likewise stopping their employments at enormous firms with a specific end goal to work for new companies. What's more, a survey drove by Economic Times likewise affirmed that the quantity of understudies joining new businesses and online business organizations has developed extensively. Without a doubt, even to pull in the best capacity on the planet; various startup firms have been taking striking moves by offering high pay packs. Indian and Foreign Investors making gigantic Investments in Startups. The startup ecosystem is getting generous support from outside and Indian speculators, who have demonstrated more confidence in the business and have given assets to help these organizations to develop a wide margin [6].Next open doors for new companies in the nation are that it is not fundamental to go abroad for the reason that India, with over a billion people, introduces a substantial home market for any products or administrations. A rising extra cash and developing yearnings of a developing working class 
have implied there is a substantial craving for brands. The vast populace has additionally prompted to a customer use development, which has thus has propped up supply and creation. New businesses that hope to administration and take into account the extensive populace in fathoming an agony point or giving an utility in one of the world's most essential buyer markets, remain to do well. As indicated by most recent Trai figures India's tele-thickness achieved 76.55 percent with a supporter base of 95.76 crore. Fundamentally remote endorser base touched 95.76 crore, barely short of 100 crore stamp. Other open door which motivating entrepenener can adventure is that high portable infiltration in urban and rustic India has reshaped the economy of the nation and how merchandise and ventures are advertised. It has prompt to more prominent efficiencies and expanded profitability. It has implied organizations benefit through speedier basic leadership, better coordination and notwithstanding something like access to ledgers. Higher versatile infiltration has additionally prompted to expanded money related incorporation and stream of credit to the unbanked. Development in portable infiltration is changing the way organizations and purchasers impart and work. With information empowered cell phones, the very way of new companies and organizations have changed. For instance, new companies that create portable applications now have a continually expanding business sector to oblige. India is at intersection where it now needs to take into account the yearnings of a billion people. India is at intersection where it now needs to consider the wishes of a billion people. Existing frameworks can end up being lacking and there is an unprecedented need to impact a billion identities and transform into an overall power. New businesses and enterprise is the most ideal route forward in turning into a learning superpower [7]

\section{Conclusion}

There has been surge of new start-ups and innovations in India in recent years. The Indian start-up ecosystem has evolved, being driven by factors such as growth in number of funds/angels, evolving technology, higher smart phone and social media penetration, growth in incubators and accelerators, younger demographics etc. Recent government initiatives like 'Start up India, Stand up India' India will only result in additional momentum in this space [1] but as it is well know that "every coin has two side" so there is few obstacles in way of Startup India like it take time, effort, and energy. Funding is a major concern for startups and small businesses. At the point when the economy failed, it made it harder to persuade financial specialists and banks alike to part with the money that is basic for development in the beginning of a business. Moreover level of learning that business consultants have about natural issues, Multi window clearances and tax assessment framework are greatest test in method for accomplishment of Startup India so government needs to do bunches of work in this heading [8].

\section{REFERENCES}

[1] Omid Sharifi, Bentolhoda Karbalaei Hossein (2015), Understanding the Financing Challenges faced By Startups in India, International Journal Of Science Technology and Management Vol No 4 Special Issue No 01, November.

[2]https://yourstory.com/2016/02/government-definition-startup accessed on 13 January 2017 on $7.30 \mathrm{Pm}$.

[3] https://www.entrepreneur.com/article/270330 accessed on 13 January 2017 on $8.30 \mathrm{Pm}$.

[4] http://www.startupcommons.org/what-is-startup-ecosystem.html

[5] http://www.iamwire.com/2015/10/nasscom-startup-ecosystem-report-2015-india-the-next-tech-hotbed/124497

[6]http://www.turningideas.com/blog/indian-startups-challenges -and-opportunities/ accessed on 14 January 2017 on 7.30 $\mathrm{Pm}$

[7] http://www.grantthornton.in/globalassets/1.-member-firms/ accessed on 15 January 2017 on $7.30 \mathrm{Pm}$.

[8]https://www.linkedin.com/pulse/opportunities-startups-india-paramjit-anand accessed on 15 January 2017 on 8.30 Pm.

\section{Author' biography with Photo}

Name: Kamaldeep Kaur

Designation: Research Scholar at IK Gujral PTU Kapurthala highway, Jalandhar, India

Email id: kamal_grewallalton@yahoo.com 